\title{
Analisis komunikasi interpersonal dan penyesuaian diri remaja
}

\author{
Yulius Mataputun ${ }^{1}$, Habel Saud ${ }^{2}$ \\ ${ }^{12}$ Universitas Cenderawasih, Indonesia
}

\begin{tabular}{l}
\hline \hline Article Info \\
\hline Article history: \\
Received Des 13rd, 2019 \\
Revised Jan 28th, 2020 \\
Accepted Feb 10th, 2020 \\
\\
\hline Keyword: \\
Komunikasi interpersonal \\
Penyesuaian diri \\
Remaja
\end{tabular}

Corresponding Author:

Yulius Mataputun,

Universitas Cenderawasih

Email: liusmataputun@yahoo.co.id

\begin{abstract}
Penelitian ini bertujuan mendeskripsikan hubungan komunikasi interposonal dengan penyesuaian diri remaja. Penelitian ini menggunakan pendekatan deskriptif kuantitatif desain korelasional. Sampel yang digunakan berjumlah 80 orang siswa MTs Baiturrahim Jayapura Papua. Pengumpulan data menggunakan angket. Data dianalisis dengan statistik deskriptif dan inferensial. Hasil penelitian menunjukkan bahwa sebagian besar remaja memiliki komunikasi interpersonal dan penyesuaian diri yang baik. Hasil pembuktian menunjukkan bahwa terdapat hubungan positif yang signifikan antara komunikasi interpersonal dengan penyesuaian diri remaja dengan nilai signifikansi $0,000>0,05$. Dengan nilai koefisiensi korelasi sebesar 0,849, berada pada kategori sangat kuat. Dari penelitian diketahui bahwa semakin tinggi komunikasi interpersonal, maka semakin baik pula penyesuaian diri remaja, begitu pula sebaliknya.
\end{abstract}

(C2020 The Authors. Published by Indonesian Institute for Counseling, Education and Therapy (IICET). This is an open access article under the CC BY license (https://creativecommons.org/licenses/by/4.0/)

\section{Pendahuluan}

Pada dasarnya manusia selain mahluk individu juga sebagai mahluk sosial. Dikatakan mahluk individu karena masing-masing individu memiliki keunikan tersendiri yang membedakan dirinya dengan orang lain. Sedangkan dikatakan mahluk sosial, karena individu dalam hidupnya tidak terlepas dengan berinteraksi orang lain dalam mencapai suatu tujuan tertentu. Seseorang yang tidak dapat berkomunikasi dan/atau berinteraksi cenderung terisolasi dengan lingkunganya. Agar individu berhasil dalam berinteraksi dengan lingkunganya, individu itu dituntut dapat menyesuaikan diri terhadap lingkungan sosialnya (Walgito, 2011). Interaksi social pun seringkali menjadi hal mutlak yang harus dilakukan oleh setiap individu.

Salah satu bentuk perwujudan dari interaksi sosial adalah dengan penyesuaian diri. Penyesuaian diri bahkan menjadi salah satu persyaratan penting bagi terciptanya kesehatan jiwa/mental setiap individu sebagai bagian dari anggota masyarakat. Seseorang dikatakan memiliki kemampuan penyesuaian diri yang kuat (well adjusted person) jika mampu melakukan proses respons-respons yang matang, efisien, memuaskan, dan sehat (Ali \& Asrori, 2004). Dengan demikian, orang yang dipandang mempunyai penyesuaian diri baik adalah individu yang telah belajar bereaksi terhadap dirinya dan lingkunganya dengan cara-cara matang, efisien, memuaskan, sehat, dan dapat mengatasi permasalahannya.

Beberapa kajian memberikan gambaran bahwa apa yang diharapkan di atas, dalam kenyataanya belum terealisasi dengan baik oleh sebagaian siswa remaja. Sejumlah remaja tidak mampu melakukan penyesuaian diri dengan baik, seperti hasil penelitian Kusdiyati dan Halimah (2011), lebih dari setengah atau 52,5 \% siswa tidak dapat menyesuaian diri dengan baik. Selanjutnya kajian Rahmah, dkk (2016) menggambarkan tentang masih banyak siswa yang belum mampu menyesuaikan diri di lingkungan panti asuhan seperti dalam menjalin 
relasi yang sehat dengan teman sebaya dan di lingkungan, kurang simpati, dan ketidakmampuan dalam mengikuti proses pembelajaran. Artinya salah satu tugas perkembangan masa remaja yang tersulit adalah yang berhubungan dengan penyesuaian social (Hurlock, 1980). Dalam perjalanan kehidupan tidak selamanya individu berhasil dalam melakukan penyesuaian diri kerena berbagai rintangan (Sunarto \& Hartono, 2008). Ketidakmampuan remaja dalam menyesuaikan diri akan berdampak buruk dalam banyak hal. Tidah hanya dalam hal menghadapi rintangan dalam proses pendidikan di sekolah, tetapi juga akan berdampak bagi kehidupan di lingkungan masyarakat yang lebih luas.

Berbagai kesulitan siswa dalam melakukan penyesuaian diri di sekolah ditampilkan dalam bentuk perilaku, seperti rendah diri, berkelahi, melanggar tata tertip sekolah, tidak melaksanakan tugas sekolah, membolos, sering terlambat ke sekolah, menentang guru, bahkan tidak segan-segan melakukan kekerasan fisik kepada guru sampai meninggal. Seperti kasus yang terjadi di Madura, penganiayaan seorang guru kesenian yang dilakukan oleh siswanya saat proses pembelajaran seni rupa hingga meninggal (Jajeli, 2018). Kondisi ini menunjukkan bahwa terdapat permasalahan dalam proses pendidikan yang dilatar belakangi oleh ketidakmampuan siswa menyesuaian diri dalam proses pembelajaran.

Fenomena masalah penyesuaian diri remaja di atas, dapat terjadi karena ketidakmampuan remaja dalam membangun komunikasi interpersonal yang baik di lingkungan sekolah. Komunikasi interpersonal terjadi anatara dua orang atau lebih yang tidak diatur secara formal, karena itu setiap orang memiliki kebebasan untuk membicarakan berbagai hal terkait dengan pengalamannya, latar belakang, isi hatinya, gagasan, harapan, perasaanya dan yang lainya kepada orang lain. Dalam komunikasi interpersonal, akan terjadi peningkatan keeratan hubungan antar individu, dapat berbagai informasi dan/atau pengetahuan serta pengalaman kepada orang lain mulai di lingkungan terdekat keluarga, sekolah bahkan akan tercermin dalam lingkungan masyarakat yang lebih luas. Itu sebabnya komunikasi interpersonal diperlukan bagi remaja karena dalam proses komunikasi dimaksud, ada proses penyesuaian diri mereka dengan lingkungan, karena makin baik komunikasi interpersonal remaja di sekolah, maka makin baik pula penyesuaian diri siswa dalam berbagai bentuk kegiatan. Jika remaja dapat menyesuaian diri dengan berbagai hal, diharapkan suasana tersebut akan berdampak pada kemampuan dalam mengikuti program pendidikan dan pengajaran di sekolah maupun di luar sekolah bahkan dapat dimungkinkan siswa mampu menyesuaikan diri dengan model-model pembelajaran melalui media sosial/online. Hasil penelitian Darmawan, dkk (2019) tentang efektivitas komunikasi interpersonal dipengaruhi oleh seberapa besar keterbukaan dari remaja yang sedang berinteraksi, sehingga dapat meningkatkan hubungan antar personal remaja tersebut, menjadi lebih dekat dan erat walaupun mereka berkomunikasi dengan menggunakan media sosial. Keterbukaan diri menjadi kunci dalam membangun komunikasi interpersonal.

Beberapa kajian empiris memperkuat urgensi keterkaitan komunikasi interpersonal dengan penyesuaian diri remaja dalam riset ini. Seperti temuan Kusumaningsih (2013) tentang adanya hubungan yang signifikan antara komunikasi interpersonal dengan penyesuaian diri. Semakin tinggi komunikasi interpersonal siswa remaja, maka semakin baik penyesuaian dirinya, begitu pula sebaliknnya. Demikian juga temuan Dewi, dkk (2014) tentang kontribusi komunikasi interpersonal terhadap penyesuaian diri siswa kelas VIII SMP Negeri 2 Sawan. Jika komunikasi interpersonalnya baik ada kecenderungan akan diikuti pula dengan kemampuan menyesuaiakan diri. Senada dengan itu Hasanah (2017) menemukan bahwa terdapat pengaruh komunikasi interpersonal dalam menurunkan problem tekanan emosi mahasiswa. Jadi, dengan dibangunnya komunikasi interpersonal dikalangan siswa, maka permasalahan-permasalahan emosi mereka dapat ditekan dan berkurangnya masalah emosi siswa akan berdampak positif dalam banyak hal, termasuk proses pembelajaran.

Madrasah Tsanawiyah (MTs) Baiturrahim Jayapura adalah salah satu sekolah yang ada di pusat kota Jayapura Provinsi Papua, tidak tertutup kemungkinan diantara siswa apalagi siswa baru mengalami masalah penyesuaian diri, karena tugas-tugas perkembangannya sebelumnya kurang berkembang dengan baik. Tugastugas perkembangan remaja yang sangat penting yaitu mampu menerima keadaan dirinya, memahami peran seks/jenis kelamin, mengembangkan kemandirian, mengembangkan tanggungjawab pribadi dan sosial, menginternalisasi nilai-nilai moral, dan merencanakan masa depan (Ali \& Asrori, 2004).

Berdasakan sejumlah data di atas, jelaslah bahwa dewasa ini banyak siswa remaja yang kurang mampu membangun komunikasi interpersonal dengan teman baru, kondisi baru, dan lingkungan baru dan yang sejenisnya acapkali berakhir dengan kegagalan studi, sementara pendidikan di usia remaja awal amat penting bukan saja karena termasuk dalam program WBPD 9 tahun (Wajib Pendidikan Dasar 9 tahun) pemerintah 
secara merata di Indonesia, tetapi lebih daripada itu, yakni peningkatan kualitas kehidupan masyarakat Indonesia yang memiliki kemampuan berkomunikasi dan menyesuaikan diri serta berdaya saing global.

Karena itu diperlukan sejumlah upaya berbagai pihak, salah satunya adalah melakukan kajian secara ilmiah dengan tujuan untuk medeskripsikan komunikasi interpersonal, penyesuaian diri remaja, dan membuktikan hubungan komunikasi interpersonal dengan penyesuaian diri remaja.

\section{Metode}

Penelitian ini menggunakan pendekatan deskriptif kuantitatif dengan desain korelasional. Populasi pada penelitian ini adalah semua siswa MTs Baiturrahim Jayapura yang berjumlah 235 orang. Kemudian mengacu kepada pendapat Arikunto (2010), peneliti mengambil $34 \%$ dari populasi untuk dijadikan sampel, yaitu sebanyak 80 siswa. Teknik penarikan sampel yang digunakan adalah teknik random sampel. Remaja yang dimaksud pada penelitian ini adalah remaja yang berstatus sebagai siswa di MTs Baiturrahim Jayapura dengan rentan umur 12-15 tahun.

Penelitian ini menggunakan angket yang disusun berdasarkan kajian teori komunikasi interpersonal (Devito, 2011) dan penyesuaian diri (Demita, 2010). Pengembangan instrument/angket mengacu dari pemodelan skala likert. Masing-masing item terdiri dari 4 pilihan. Pengujian validitas dan reliabilitas instrumen digunakan dua cara, yaitu secara subjektif kualitatif dan Uji coba instrument. teknik analisis data yang digunakan adalah persentase dan statistik inferensial (korelasi product moment). Data dianalisis dengan bantuan program SPSS versi 2016.

\section{Hasil dan Pembahasan}

Berdasarkan hasil analisis diberoleh temuan penelitian sebagai berikut. Pertama, komunikasi interpersonal siswa remaja di MTs Baiturrahim Kota Jayapura Provinsi Papua dapat dikategorikan sudah baik, dan hal ini dialami $63(78,8 \%)$ atau sebagian besar siswa. Hal itu dapat dilihat dari aspek keterbukaan, empati, sikap positif, dan keteraan telah dipraktikkan siswa dalam kehidupan sehari-hari terutama di sekolah dengan baik (Devito, 2011).

Komunikasi interpesonal memuat dua unsur yaitu proses pertukaran informasi dan percakapan umpan balik (Indriati, 2017; Maulana, 2016).Siswa dalam membangun hubungan dengan orang lain mempertunjukkan sifat dan karakter keterbukaan, turut merasakan apa yang dialami orang lain, dapat mendengar dan menerima pendapat orang lain, menghargai keberagaman dan orang yang lebih tua usianya. Hasil penelitian Fitra (Fitra, 2014) menunjukkan terdapat pengaruh yang signifikan antara kemampuan komunikasi interpersonal terhadap prestasi belajar matematika siswa SMP Kemala Bhayangkari 1 Medan Tahun Pelajaran 2014/2015. Didukung oleh penelitian Kamaruzzaman (2016) tentang komunikasi interpersonal siswa yang berada pada kategori cukup baik. Kajian selanjutnya dilakukan oleh Purnomo dan Harmiyanto (2016), yang menemukan sebagian besar siswa kelas X SMAN 1 Garum Kabupaten Blitar memiliki keterampilan komunikasi interpersonal tinggi. Kondisi yang sama juga terjadi di SMP Negeri 1 Sipis Pi, komunikasi interpersonal siswa berada pada kategori tinggi (Sahputra, 2018). Keterampilan dalam berkomunikasi interpersonal sangat efektif dalam mencegah, meringankan dan mengatasi stress yang negative (Durrant et al., 2013). Artinya masalah dalam proses pembelajaran dapat diatasi antara lain dengan membangun komunikasi interpersonal. Dalam komunikasi interpersonal dibangun suasana komunikasi antar pribadi. Kesulitan dalam pembelajaran dapat dibicarakan ke dalam (internal) baik dengan sesama siswa maupun tenaga pendidik yang profesional.

Jika dilihat dari aspek tujuan komunikasi interpersonal dikemukakan Ali dan Muhammad (2004) yaitu menemukan diri sendiri, menemukan dunia luar, membentuk hidup penuh arti, berupa sikap dan tingkah laku, untuk bermain dan kesenangan, dan untuk membantu, maka suasana dan keharmonisan hidup siswa akan semakin baik dan terasa dalam berbagai kegiatan intrakurikuler, kokurikuler, dan ektrakurikuler. Sejumlah kegiatan berjalan dengan tingkat kendala yang kurang berarti dengan tingkat kesuksesan yang terukur. Dengan demikian sekolah telah mendukung program pemerintah terkait dengan pembangunan dan penguatan karakter peserta didik/siswa sesuai Permendikbud Nomor 20 Tahun 2018. Tugas sekolah selanjutnya adalah mempertahankan bahkan mengembangkan sejumlah kegiatan yang selama ini telah berjalan dengan baik dan 
mengidentifikasi siswa yang masih kurang optimal berkomunikasi antar pribadi yang dialami sebagian kecil atau 17 (21,25\%) siswa. Sekolah/guru pembimbing dapat memprogramkan pelayanan Bimbingan Kelompok (BKp) topik tugas dengan pentingnya membangun komunikasi interpersonal dan yang sejenisnya.

Kedua, hasil penelitian ini juga memberikan gambaran bahwa terdapat $65(81,3 \%)$ atau sebagian besar siswa mampu penyesuaian diri dengan baik. Siswa dalam kehidupan setiap hari mampu menyesuaikan dengan lingkungan sekitar. Hal ini dilihat dari indikator penyesuaian diri yaitu kematangan emosi, intelektual, sosial, dan tanggungjawab telah diterapkan siswa dengan baik (Demita, 2010). Penyesuaian diri adalah usaha manusia untuk mencapai keharmonisan pada diri sendiri dan pada lingkungannya (Adiningtiyas, 2016; Mustaqim, 2014; Wiratsongko, 2016). Hasil penelitian tersebut memberikan dua makna yang berarti dalam upaya penguatan karakter peserta didik yaitu satu sisi siswa diharapkan mampu menyesuaian diri dengan pribadinya, tetapi juga mampu menyesuaian diri dengan lingkungan disekitarnya mulai dari lingkungan keluarga, sekolah bahkan masyarakat yang lebih luas. Siswa telah memiliki sejumlah kemampuan seperti dalam mengendalikan diri, memahami dan menghargai potensi setiap orang, kepekaan terhadap orang lain dan terlebih memiliki tanggungjawab.

Masalah penyesuaian diri pada sampel jenjang SMA dilakukan Utami (2016) dengan hasil sebagian besar $(68,18 \%)$ siswi kelas X SMA Tarakanita 1 memiliki penyesuaian diri yang baik dan sangat baik. Jadi, hasil penelitian ini memperkuat penelitian sebelumnya bahwa sebagaian besar siswa yang memiliki penyesuaian diri yang baik. Juga, hasil penelitian Suryadi dan Usman (2018) menunjukkan bahwa penyesuaian diri siswa secara umum tergolong pada kategori baik. Siswa dapat menyesuaikan diri dengan tata tertib, guru, teman sebaya dan sarana dan prasarana.

Program dan sejumlah kegiatan mendukung hasil penelitian ini terkait penyesuaian diri siswa yang sedang berjalan perlu diteruskan bahkan dikembangkan lagi, karena masih terdapat sebagian kecil atau $15(18,75 \%)$ siswa kurang mampu dalam menyesuaikan diri. Karena itu sekolah/guru pembimbing dalam menindaklanjuti temuan ini diantaranya guru pembimbing dapat melaksanakan sosiometri untuk mengidentifikasi siswa yang perlu mendapat penangan Konseling Perorangan (Kp) dan/atau Konseling Kelompok (KKp). Selain itu dapat juga memantapkan program pelayanan orientasi dan informasi yang terintegrasi dalam kegiatan Masa Orientasi Siswa (MOS) terkait keberadaan sekolah baik dengan visi-misi, struktur, dan budaya sekolah terutama dalam proses pembelajaran.

Ketiga, luaran penelitian ini selain mendeskripsikan komunikasi interpersonal dan penyesuaian diri siswa remaja sebagaimana telah dipaparkan sebelumnya, juga ditemukan terdapat hubungan positif signifikan komunikasi interpersonal dengan penyesuaian diri siswa remaja sebesar 0,000 $>0,05$ dengan nilai koefisiensi korelasi sebesar $0,849(\mathrm{r}=0,849)$ atau berada pada kategori sangat kuat/tinggi dengan parameter pengukuran nilai korelasi antara 0,80-1,000. Makin tinggi komunikasi interpersonal, maka makin baik pula penyesuaian diri remaja, begitu pula sebaliknya makin rendah komunikasi interpersonal, maka semakin rendah pulah tingkat penyesuaian diri remaja. Individu yang kurang komunikasi akan meninimbulkan kurang percaya diri dan depresi dibandingkan dengan orang yang senang berkomunikasi (Cangara, 2000). Artinya penting bagi siswa untuk membangun komunikasi yang baik, karena untuk menjalani proses pendidikan yang panjang diperlukan komunikasi/interaksi dengan orang lain termasuk komunikasi antar pribadi dengan teman-teman sebaya dan yang lainya sebagai bagian dari tugas perkembangan anak remaja.

Kajian empirik komunikasi interpersonal yang sejalan dengan penelitian ini, antara lain dilakukan Dewi, dkk (Dewi et al., 2014) mengatakan bahwa terdapat kontribusi komunikasi interpersonal terhadap penyesuaian diri siswa kelas VIII SMP Negeri 2 Sawan memiliki hubungan positif dengan nilai ry $=0,883$. Besar kontribusi komunikasi interpersonal terhadap penyesuaian diri siswa adalah 77,97\%. Kajian Mansouri, dkk (2016) membuktikan bahwa ada hubungan positif dan signifikan antara kemampuan berkomunikasi dengan penyesuaian diri yang berhubungan dengan penyesuaian sosial, emosional, pendidikan, tujuan, dan kemandirian siswa. Dari kedua kajian tersebut, memberikan penekanan bahwa komunikasi interpersonal siswa remaja, dapat berkontribusi positif terhadap penyesuaian diri siswa lebih baik, Bahkan hasil penelitian Utomo dan Harmiyanto (2016)mengatakan bahwa terdapat hubungan yang signifikan antara keterampilan komunikasi interpersonal dengan kepercayaan diri siswa kelas X di SMAN 1 Garum Kabupaten Blitar. Hal ini membuktikan bahwa siswa yang memiliki keterampilan komunikasi interpersonal tinggi maka rasa kepercayaan dirinya tinggi. Kepercayaan diri tinggi akan membawa peserta didik pada sifat optimis dalam menjalani pendidikan, bahkan 
dapat dijadikan modal awal yang akan menentukan keberhasilan siswa itu sendiri bahkan dapat diberdayakan potensi ini untuk membangun orang lain.

Berdasarkan paparan hasil penelitian dan pembahasan sebelumnya, ternyata sebagian besar siswa remaja di MTs Jayapura Provinsi Papua memiliki potensi dan/atau kemampuan dalam membangun komunikasi interpersonal, penyesuaian diri yang baik, bahkan terbukti memiliki hubungan positif dan signifikan yang sangat kuat. Hasil kajian ini dapat ditindaklanjuti dalam rangka mengembangkan mutu sekolah/lulusan dan kepentingnya pendidikan lainya. Sekolah/guru pembimbing dapat memanfaatkan data kajian ini misalnya dengan mengoptimalkan potensi siswa dalam program Bimbingan Teman Sebaya (BTS) seperti sosialisasi bahaya Narkoba dan pelayanan konseling bagi teman-temanya yang mengalami masalah komunikasi interpersonal dan penyesuaian diri. Dapat juga dimanfaatkan membantu sekolah untuk mengkaderkan siswa menjadi seorang pemimpin yang memiliki kemampuan dalam membangun komunikasi dan dapat menyesuaikan diri dalam berbagai kegiatan intrakurikuler kokurikuler, bahkan ekstrakurikuler (program pengembangan diri siswa). Untuk itu sekolah perlu mengagendakan program penguatan potensi dimaksud, seperti pelatihan kepemimpinan dan BTS untuk mempersiapkan siswa secara baik dalam membantu sekolah sekaligus mengembangkan potensi mereka.

Implikasi selanjutnya dari hasil penelitian ini adalah pertama, sekolah perlu mempertahankan bahkan mengembangkan sejumlah program/kegiatan sedang berjalan di MTs Jayapura, terutama yang berhubungan dengan pengembangan aspek komunikasi interpersonal (keterbukaan, empati, sikap positif, dan kesetaraan) dan penyesuaian diri remaja (kematangan emosi, intelektual, sosial, dan memiliki tanggungjawab) dalam beragam program/kegiatan intrakurikuler, kokurikuler, dan ekstrakurikuler secara terintegrasi. Dalam pembelajaran dioptimalkan model pembelajaran yang menekankan kemampuan berkomunikasi dan menumbuhkan rasa percaya diri misalnya dengan tugas kelompok dan/atau diskusi/prentasi. Kedua, guru pembimbing dapat mengoptimalkan program pengembangan diri melalui berbagai kegiatan, terutama bagi sebagaian kecil siswa/remaja yang masih menghadapi masalah dalam berkomunikasi antar pribadi/interpersonal dan penyesuaian diri, misalnya dengan kegiatan Bimbingan Kelompok (BKp) topik tugas (membangun komunikasi antar pribadi) dan layanan orientasi dan informasi tentang penyesuaian diri di lingkungan sekolah dan masyarakat yang terintegrasi dalam Masa Orientasi Siswa (MOS). Selain itu dapat dilakukan kegiatan sosiometri untuk melihat hubungan sosial siswa dalam satu kelas, dan akan ditindaklanjuti dengan Konseling Perorangan (Kp). Ketiga, oleh karena sebagaian besar siswa memiliki potensi komunikasi interpersoal dan penyesuaian diri yang baik, maka sekolah/bagian kesiswaan/guru pembimbing dapat memanfaatkan dan/atau mengoptimalkan potensi mereka untuk membantu sekolah/guru pembimbing dalam berbagai kegiatan dalam program Bimbingan Teman Sebaya (BTS) seperti sosialisasi bahaya Narkoba dan pelayanan konseling bagi teman-temanya. Keempat, penelitian ini diharapkan menjadi salah satu referensi dalam menyiapkan siswa berkarakter, mampu berkomunikasi dan menyesuaiakan diri di era global dan sebagai rujukan penelitian serupa dengan mengembangan variabel dan pendekatan yang lain seperti menindaklanjutinya dengan melihat pengaruh kedua variabel dalam penelitian ini dengan hasil belajar siswa.

\section{Kesimpulan}

Berdasarkan analisis dan pembahasan penelitian ini, maka dapat disimpulkan bahwa sebagian besar komunikasi interpersonal remaja berada pada kategori baik dengan persentase $78,8 \%$. Demikian juga dengan penyesuaian diri berada pada kategori baik dengan persentase $81,3 \%$. Hasil pembuktian menunjukkan bahwa terdapat hubungan positif signifikan komunikasi interpersonal dengan penyesuaian diri remaja dengan nilai signifikansi $0,000>0,05$ dan nilai koefisiensi korelasi sebesar 0,849 atau berada pada kategori sangat kuat. Makin tinggi komunikasi interpersonal, maka makin baik pula penyesuaian diri remaja, begitu pula sebaliknya.

\section{Referensi}

Adiningtiyas, S. W. (2016). Hubungan Kecerdasan Emosi dengan Penyesuaian Diri Siswa di Sekolah. KOPASTA: Jurnal Program Studi Bimbingan Konseling, 2(2).

Ali, M., \& Asrori, M. (2004). Psikologi remaja: Perkembangan peserta didik.

Arikunto, S. (2010). Metodologi penelitian, PT. Rineka Cipta, Jakarta. 
Cangara, H. (2000). Pengantar ilmu komunikasi.

Darmawan, C., Silvana, H., Zaenudin, H. N., \& Effendi, R. (2019). Pengembangan hubungan interpersonal remaja dalam penggunaan media sosial di Kota Bandung. Jurnal Kajian Komunikasi, 7(2), 159-169.

Demita. (2010). Psikologi Perkembagan Pesertadidik. Bandung: Remaja Rosdakarya.

Devito, J. A. (2011). Komunikasi Antar Manusia. Tangerang. In: Karisma Publishing Group.

Dewi, K. K. S., Sedanayasa, G., Antari, N. N. M., \& Erg, M. (2014). Kontribusi Komunikasi Interpersonal terhadap Penyesuaian Diri Siswa Kelas VIII SMP Negeri 2 Sawan Tahun Pelajaran 2013/2014. Jurnal Ilmiah Bimbingan Konseling Undiksha, 2(1).

Durrant, A., Hook, J., McNaney, R., Williams, K., Smith, T., Kipling, M. (2013). Design to support interpersonal communication in the special educational needs classroom. Paper presented at the Proceedings of the 12th International Conference on Interaction Design and Children.

Fitra, A. (2014). Pengaruh Kemampuan Komunikasi Interpersonal terhadap Prestasi Belajar Matematika Siswa SMP Kemala Bhayangkari 1 Medan Tahun Ajaran 2014/2015. Jurnal Mantik Penusa, 15(1).

Hasanah, H. (2017). Pengaruh Komunikasi Interpersonal dalam Menurunkan Problem Tekanan Emosi Berbasis Gender. Sawwa: Jurnal Studi Gender, 11(1), 51-74.

Hurlock, E. B. (1980). Psikologi perkembangan. Jakarta: erlangga.

Indriati, N. (2017). Komunikasi Interpersonal Dalam Lingkungan Panti Asuhan Walisongo. KINESIK, 4(1).

Jajeli, R. (2018). Guru Tewas Dianiaya Murid, Persatuan Guru akan Gelar Aksi Solidaritas. Retrieved from https://news.detik.com/berita-jawa-timur/d-3855365/guru-tewas-dianiaya-murid-persatuan-guru-akangelar-aksi-solidaritas

Kamaruzzaman, K. (2016). Analisis Keterampilan Komunikasi Interpersonal Siswa. Jurnal Konseling Gusjigang, 2(2).

Kusdiyati, S., \& Halimah, L. (2011). Penyesuaian diri di lingkungan sekolah pada siswa kelas XI SMA pasundan 2 bandung: Universitas Ahmad Dahlan.

Kusumaningsih, M. R. (2013). Hubungan antara Komunikasi Interpersonal dengan Penyesuaian Diri pada Siswa Remaja. Character: Jurnal Penelitian Psikologi., 2(1).

Mansouri, M., Khorshidzade, M., \& Asgari, A. (2016). Relationship of spiritual intelligence components with students' adjustment (Hubungan Perkaitan Komponen Kecerdasan Spiritual dengan Kesesuaian Pelajar). Jurnal Pendidikan Malaysia (Malaysian Journal of Education), 41(1), 25-32.

Maulana, R. (2016). Definisi Komunikasi Interpersonal. Retrieved from https://psikologihore.com/definisikomunikasi-interpersonal/

Mustaqim, I. (2014). Proses dan Aspek-Aspek Penyesuaian Diri. Retrieved from https://imammalik11.wordpress.com/2014/04/14/proses-dan-aspek-aspek-penyesuaian-diri/

Rahmah, S., Asmidir, A., \& Nurfahanah, N. (2016). Masalah-Masalah yang Dialami Anak Panti Asuhan dalam Penyesuaian Diri dengan Lingkungan. Konselor, 3(3), 107-112.

Sahputra, D. (2018). Komunikasi Interpersonal pada Siswa serta Implikasinya dalam Pelayanan Bimbingan dan Konseling. JUANG: Jurnal Wahana Konseling, 1(2), 14-21.

Sunarto, H., \& Hartono, A. (2008). Perkembangan peserta didik. Jakarta: Rineka Cipta.

Suryadi, S., \& Usman, C. I. (2018). Profil Penyesuaian Diri Siswa Di SMP Pembangunan Laboratorium UNP Padang. JURNAL EDUKASI: Jurnal Bimbingan Konseling, 4(1), 89-101.

Utami, M. B. (2016). Hubungan antara Harga Diri dan Penyesuaian Diri Siswi Kelas X SMA Tarakanita 1. Psiko Edukasi, 14(1), 68-77.

Utomo, D. P., \& Harmiyanto, H. (2016). Hubungan Keterampilan Komunikasi Interpersonal dan Kepercayaan Diri Siswa Kelas X SMAN 1 Garum Kabupaten Blitar. Jurnal Kajian Bimbingan dan Konseling, 1(2), 55 59.

Walgito, B. (2011). Psikologi Sosial Sebuah Pengantar. In: Yogyakarta: CV Andi Offset.

Wiratsongko, B. (2016). Penyesuaian diri anak berkebutuhan khusus di SDN inklusi Pulutan Wetan II. Jurnal Riset Mahasiswa Bimbingan Dan Konseling, 5(3). 